مجلة الفنون والندب وعلـوم الإنسانــيات والاجتهـاع

Journal of Arts, Literature, Humanities and Social Sciences

www.jalhss.com ISSN online: $2414-3383$ ISSN print: $2616-3810$

العدد (36) الذار - هارس 2019

\title{
A Pragmatic Analysis of Speech Acts in Short Surahs of the Holy Quran
}

\author{
Lecturer \\ Huda Hadi Badr \\ Department of English \\ College of Arts \\ University of Thi-Qar \\ Iraq
}

\author{
Dr. A.Ali Hammood \\ Shihan Al.Saidi \\ Department of English \\ College of Arts \\ University of Thi-Qar
}

Iraq

\author{
Lecturer \\ Sahab Salih Fenjan \\ Department of English \\ College of Arts \\ University of Thi-Qar \\ Iraq
}

\begin{abstract}
This study examines speech acts in two short surahs of the Quran. It aims at delving into the illocutionary speech acts and their pragmatic functions in surah Ad-dhuha and surah As-sharah, in addition, direct and indirect speech acts have also been investigated. The importance of this study lies in investigating speech acts and their pragmatic functions in the aforementioned Quranic verses, in addition to the reasons behind their occurrence to help get a deep understanding of these verses.

Data on the translation of the source text have been collected from the Quran and its books of tafsir. Eleven examples, related to speech acts, have been selected for analysis on the basis that they have not been tackled pragmatically before and they include many direct and indirect speech acts. Moreover, they comprise underlying pragmatic functions that are not said in the text. Qualitative content analysis has been used to examine the source data by consulting the widely used traditional exegetical and rhetorical books to determine the source text intentionality. Additionally, the present study concludes that two types of illocutionary speech acts which are directives and commissives are performed in the previously mentioned surahs. Furthermore, only two pragmatic functions which are ordering and promising occur. All the directives occur as direct speech acts and all the commissives occur as indirect speech acts. The circumstances in which these two short surahs were revealed and the effect intended to achieve on the recipients are reasons that might determine the occurrence of direct and indirect speech acts.
\end{abstract}




\subsection{Introduction}

The present research is a pragmatic study of speech acts in religious discourse in Standard Arabic. Religious discourse is regarded as one of the most influential and important kinds of discourse since it includes divine messages. The noble Quran, being a type of this discourse, is considered the holy book of all Muslims who turn to for guidance in all aspects of their life. Although many studies have been conducted to investigate speech acts theory in the Qura'nic discourse, they have either focused on speech acts syntactically and/ or semantically or they have dealt with speech acts from a translational perspective ( see Al-Saaidi, et al. 2013;Issa, 2015; Mawadda, 2016; Santosa, et al. 2017, among others). As such, the researchers delve into the pragmatic analysis of illocutionary speech acts and their pragmatic functions in two short surahs of the holy Quran, namely Ad-dhuha and As-sharah. The present study has two objectives which are put in the form of questions as below:

1- What are the illocutionary speech acts and the pragmatic functions performed in surah Ad-dhuha and surah As-sharah?

2 - Are direct or indirect speech acts frequently performed in these two short surahs? And why?

The two short surahs mentioned above are analyzed according to Searle's (1969) model, tackling illocutionary speech acts specifically. Direct and indirect speech acts are also examined and analyzed.

\subsection{Literature Review}

This part of the study is concerned with providing a brief critical examination of the related previous studies that have investigated speech acts in the Qur'an. In addition, these related studies are briefly examined in terms of their focus, significance and findings.

Al-Saaidi, et al. (2013) attempt to investigate the act of prohibition to show how this kind of speech act is used in the Quran and the Bible. The researchers analyzed the act of prohibition syntactically, semantically and pragmatically. The main findings of their study are that prohibition in English is most commonly realized by negative imperative" do not do". However, in Arabic, prohibition is heavily used explicitly and implicitly. Furthermore ,Jauharin (2014) investigated types and functions of directives in Surah al-Baqarah where the researcher applied a descriptive qualitative approach focusing on the English translation of the said surah. The study concluded that the dominant directives in the translations examined are command and order, respectively.

Quite relatedly, Issa, (2015) conducted a research on the translation of requests in the Quran. The researcher provides a descriptive, comparative and analytical study of request, particularly imperative, as a speech act via analyzing its function in the translations of the Quran. The researcher concluded that despite the fact that Arabic and English are linguistically different, translators of the Quran strive to provide the same style, form and pragmatic function via using certain strategies such as addition, substitution and explanation. The selected translators succeed sometimes and failed at other times, and, consequently, part of the Qur'anic meaning is lost. 
In a relevant study, Mawadda, (2016) studied commissive utterances in the translation of surah Joseph pragmatically. The researcher focused on the types of commissives in the said surah and the politeness strategies utilized. Based on Brown and Livenson, the study reveals that six types of commissive utterance are used in the surah examined, namely, promising, warning, threatening, volunteering, refusing and offering. In addition, four politeness strategies are employed: bald on record, positive politeness, negative politeness and bold off record. In the same context, Amin and Safa (2016) examined speech act of imperative in terms of the relationship of structure and context within. The study revealed that the illocutionary acts that are basically used in the Koran stories are: assertive, directive, commissive, commissive directive, expressive, expressive directive and declarative.

Through content analysis, Santosa, et al. (2017) utilized speech act theory to understand the meaning questions in the Quran express contextually. The results of the study showed that questions in the Qur'an are mostly not used in their original meaning but they are rather utilized to convey another meaning. Accordingly, the function of questions is no more the same. The sentences with question words are not interpreted as interrogative sentences.

With all this in mind, it seems obvious that all the above-mentioned studies have mainly dealt with speech acts in the Qur'an from the translational perspective focusing on identifying the translator's failure in comprehending and rendering the Qur'anic intended meaning accurately. In addition, those studies which are basically concerned with speech acts, regardless of their translation, have never touched upon the explicit and/or implicit pragmatic functions of the speech acts under analysis. The significance of the present study stems from investigating speech acts in the Quran from a pragmatic-based discourse analysis identifying the related pragmatic functions.

\subsection{Theoretical Framework}

\subsubsection{Speech Acts Theory}

Verschueren( 1999) states that in response to logical positivism in which the utterance is assessed as being true or false, John L. Austin inspired a speech acts theory in which language is perceived as being a tool by which we can do things. Speech act refers to " a theory which analyses the role of utterances in relation to the behaviour of speaker and hearer in interpersonal communication"( Crystal, 2003: 427). Austin introduced his notions on this theory in lectures in 1955 and then they were published in 1962 under the title " How to Do Things with Words". In the course of time, John R. Searle (1969), who was Austin's student, modified and developed this theory (Mey,1993). In this theory, Austin distinguished between two types of utterances: constatives and performatives. Constatives are utterances that are assessed according to whether they are true or false whereas performatives are utterances that are assessed according to whether they are felicitous or not( Levinson,1983). The following examples explain the difference between the two:

1- We went down to Como(Verschueren, 1999:22).

This sentence is constative if it is said as a statement that can be assessed as true or false (Ibid). 
2-I give and bequeath my watch to my brother(Austin,1962:5).

Since there is an action of bequeathing, this sentence is performative(Ibid).

Later, Austin has rejected the constatives- performatives distinction and favored a general theory of speech acts in which both performatives and constatives are considered special sub-cases. In this respect, he concludes that both constatives and performatives are subject to felicity conditions and sometimes constatives and performatives cannot be distinguished even in terms of truth or falsity( Huang,2006).

Austin made a distinction between explicit performatives and implicit or primary performatives. Explicit performatives are utterances that are performed by the use of performative verbs( Yule,1996). Fromkin, et al.(1996) state that performative verbs are verbs by which we do things and which make the illocutionary force explicit. On the other hand, implicit performatives are speech acts that are achieved without the use of performative verbs( Yule,1996).

According to Austin, there are three types of acts that are constituted by the same utterance simultaneously. These acts are as follows :

1- A locutionary act: The act in which a string of sounds or words are produced to create a meaningful linguistic expression (Cruse,2006).

2- An illocutionary act: The act performed when the utterance is produced by a speaker to communicate his intention to a hearer(Ibid). An illocutionary act is referred to as a speech act in its narrow sense. For example, when John says to Mary "pass me the glasses, please", an illocutionary act of ordering or requesting is performed. Such an act is also referred to as the illocutionary force or the illocutionary point of the speech act. (Huang, 2012). The illocutionary force is also referred to as a pragmatic function. Al-Saidi(2016:18) based on Searle (1969) and Baker(2011) defines the pragmatic function as "the illocutionary force a given speech act entails in addition to the meaning it expresses and it refers to the embedded associative connotations of a word or an expression that carries implicit meanings".

3- A perlocutionary act: The act constituted when a speaker produces an utterance to make an effect on a hearer.

When speaking, all the three acts mentioned above are usually performed by the speaker at the same time, but a distinction is made between them for analytic purposes (Coulthard,1985). In addition, the previously mentioned distinction helped Austin to inspire a model consisting of five classes of speech acts(Austin,1962). His model is developed by his student Searle later.

\subsubsection{Searle's Taxonomy of Speech Acts:}

Since Austin's classificatory system of speech acts is not flawless, many attempts have been made to develop his classification. One of these attempts was Searle's taxonomy which is considered the most influential tool for analysis. The criteria depended on by Searle to construct his classification of speech acts are: illocutionary point, direct of fit between words and world, expressed psychological state and propositional content (Huang,2012). Searle(1979) classifies speech acts as follows:

1- Representatives are acts that are assessed along the dimension of truth. Examples are concluding, deducing...etc. 
2- Directives are acts performed by the speaker to make the hearer do something. The verbs belonging to this type of speech acts are command, request, pray, permit, advise...etc.

3- Commissives are acts in which the speaker commits himself/ herself to do something in future. This class involves promises, threats, offers, refusals...etc.( Huang,2006).

4- Expressives are acts that express the psychological state of the speaker. Paradigmatic cases are thanking, condoling, congratulating...etc. (Searle,1979).

5- Declarations are acts in which the speaker makes a correspondence between the reality and the utterance(Ibid). For example, nominating a candidate, firing from employment and declaring war are among cases belonging to this kind of speech acts( Huang,2006).

\subsubsection{Direct and Indirect Speech Acts:}

People prefer to use indirectness when communicating with others because it has a relationship to politeness. It helps avoid giving unpleasant messages to the recipients(Leech,1983). Bach and Harnish(1979) mention that sometimes when performing a speech act, what is meant is more than what is said and in this case an indirect speech act occurs. Indirect speech acts are acts that occur when "there is an indirect relationship between a structure and a function"(Yule,1996:55). Direct speech acts are acts that occur when" there is a direct relationship between a structure and a function"(Ibid:54). Searle(1979) introduced the notion of primary and secondary illocutionary acts. The primary illocutionary act is the indirect one whereas the secondary illocutionary act is the direct one. In order for the speaker to successfully perform the indirect speech act and in order for the hearer to understand both primary and secondary illocutionary acts at once, they need shared knowledge, in addition, the hearer must be able to infer what the speaker means.

Searle (ibid) provides an example of primary and secondary illocutionary acts:

3- Student X: Let's go to the movies tonight(ibid:33).

4- Student Y: I have to study for an exam(ibid).

In sentence (1), X makes a proposal of going to the cinema and in sentence(2), $\mathrm{Y}$ rejects this proposal. $\mathrm{X}$ understands from Y's statement that he/ she is unable to go tonight. Y's statement is called the secondary illocutionary act and Y's rejection the primary illocutionary act(Ibid).

\subsection{Methodology}

\subsubsection{Research Approach}

This study is qualitative since it is mainly based on text analysis of the data collected, which are descriptively examined.

\subsubsection{Data of the Study}

The data of this study were extracted from the Qur'an. They consist of (11) speech acts in the Qur'an. In addition, the context of the selected samples of speech acts is provided by consulting the books of Tafsir, such as Al-Razī (1981) and Qutb(1992).

\subsubsection{The Rationale for data Selection}

The rational for selecting the verses representing speech acts in the Qur'an is detailed below: 
1- They have never studied pragmatically before.

2-They are full of direct and indirect speech acts.

3-Both the direct and indirect speech acts convey intended pragmatic functions that are not said in the text.

\subsubsection{Data Analysis}

For the sake of analysis, two short surahs, namely Ad-dhuha and As-sharah are extracted from the holy Quran. Direct and indirect speech acts in these two short surahs, along with their pragmatic functions, are analyzed according to Searle's(1969) model. This adopted model involves five classes of speech acts. Only (11) examples are mentioned in this section and for other Quranic verses, ( see Appendix A and Appendix B). In addition, symbols used in the transliteration of the verses analyzed in this study are adopted from the web site: https://www.islamicfinder.org/

\subsection{Results and Discussions}

\subsubsection{Analysis of Surah Ad- dhuha (Morning Brightness)}

This surah is considered one of the short surahs of the holy Quran and it comprises eleven verses. Only two types of speech acts (directive and commissive) occur in this surah. It also contains two types of pragmatic functions which are promising and ordering. Concerning the context of situation, this surah was revealed after a period of silence where no revelation was received by the prophet Muhammed for six months (AlRazī1,1981;Qutb,1992). Accordingly, the prophet felt quite disconnected from Allah and this period of his life was very unbearable. That's why, Allah revealed this surah to console His prophet, remove his distress and anxiety and give him a message of hope by asserting that his later life will be full of victory and satisfaction (Ali, 1998).

\section{Direct and Indirect Speech Acts of Directive:}

In the surah under study, this type of speech acts occurs with a low frequency of occurrence, containing only three examples. All of them are direct of ordering pragmatic function, forming $27 \%$ out of the total (11). Consider the following example:

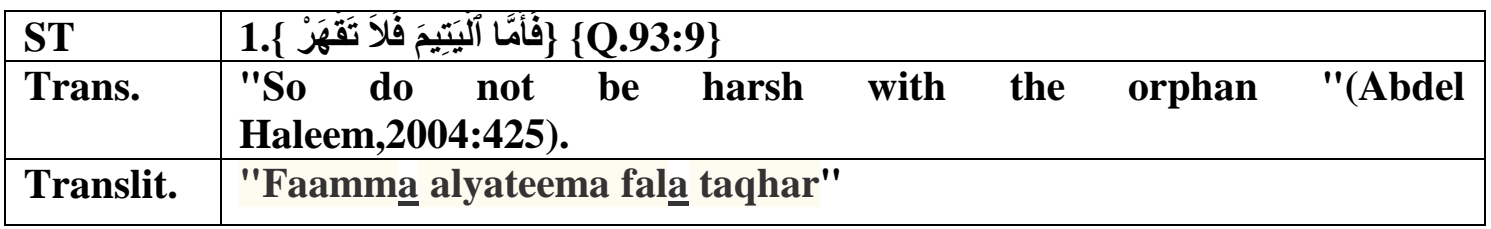

The word 'taqhar' means 'prevalence with oppression'(IbnManzur,1997). This verse has a meaning related to verse (6), which is mentioned under the category of commissives in example (5), in which Allah reminded the prophet Muhammed of his past life when he suffered from the pain of orphanhood and how Allah sheltered him. Reminding the prophet of his orphanhood, Allah orders him in this verse to be kind to orphans and never humiliate them or appropriate their wealth(Al-Razī,1981;Qutb,1992). Based 
on Searle(1969), since this verse involves an explicit order of safeguarding the orphan's rights, it is a direct speech act of directive entailing a pragmatic function of ordering in which the importance of highly considering the orphan's rights is stressed.

\section{Direct and Indirect Speech Acts of Commissive:}

This kind of speech acts extensively occurs in the surah under analysis. Indirect speech acts of this type are eight and there is no instance of direct speech acts. All the pragmatic functions in this surah are of promising, making up 72\% out of the total (11). The following are good examples:

\begin{tabular}{|c|c|}
\hline ST & 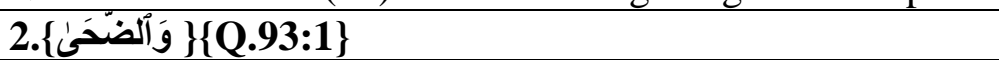 \\
\hline Trans. & "By the morning brightness"(Abdel Haleem,2004:425). \\
\hline Translit. & "Waaldduha" \\
\hline
\end{tabular}

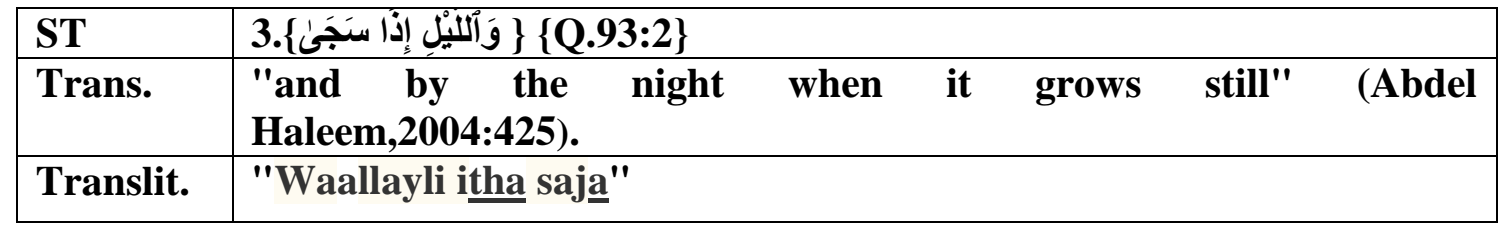

\begin{tabular}{|c|c|}
\hline ST & 4. 4. \\
\hline Trans. & $\begin{array}{l}\text { "your Lord has not forsaken you [Prophet], nor does He hate } \\
\text { you" (Abdel Haleem,2004:425). }\end{array}$ \\
\hline Translit. & "Ma waddaAAaka rabbuka wama qalä" \\
\hline
\end{tabular}

According to IbnManzur (1997), the expressions 'aldduha' and 'saja ' mean morning brightness and night when it gets more darkened. In addition, the expression 'ma waddaAAaka rabbuka wama qala' means that Allah did not hate or leave the prophet Muhammed.

The three verses above were revealed after the revelation has not come to the prophet Muhammed for some time. The forenoon (which is the morning) and the night (when everything is enveloped by its darkness) were taken an oath on by Allah to emphasize that the discontinuation of the revelation in a while was not because $\mathrm{He}$ left or hated His prophet Muhammed as disbelievers claimed to hurt him. But it stopped temporarily due to Allah's discretion. In these verses, the forenoon and the night are images for the revelation and its stoppage for some time.(Al-Razī,1981;Qutb,1992). Based on Searle(1969), these three verses are not representative speech acts of asserting pragmatic function as it appears from the structure. Rather, they are commissive speech acts of promising pragmatic function in which Allah promises the prophet that $\mathrm{He}$ will never forsake him and $\mathrm{He}$ will always be with him to reduce the hurt caused by disbelievers when they claimed that Allah abandoned his prophet after a brief interval happened in the revelation. 


\begin{tabular}{|c|c|}
\hline ST & 5.\{أَ \\
\hline Trans. & $\begin{array}{l}\text { "Did He not find you an orphan and shelter you?"(Abdel } \\
\text { Haleem,2004:425). }\end{array}$ \\
\hline Tra & " Alam yajidka yateeman faawa $\underline{\text { a }}$ \\
\hline
\end{tabular}

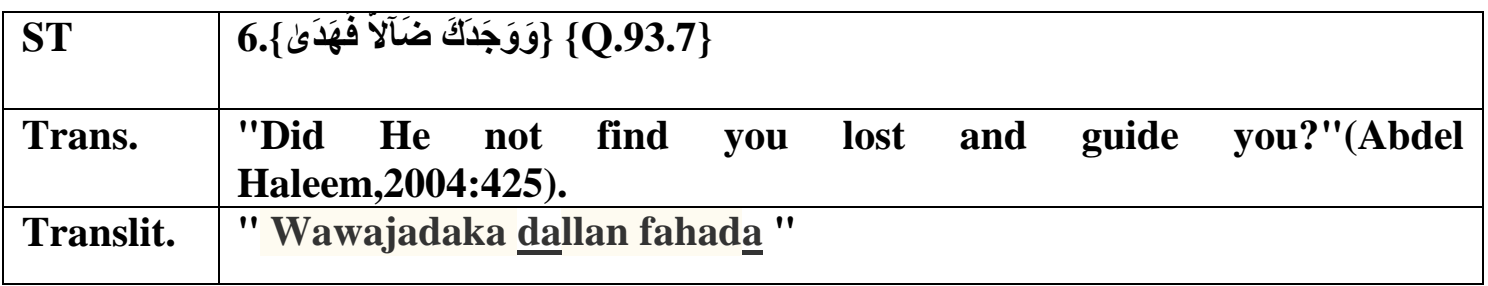

\begin{tabular}{|c|c|}
\hline ST & 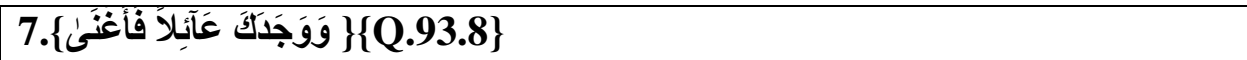 \\
\hline Trans. & $\begin{array}{l}\text { "Did He not find you in need and make you self- } \\
\text { sufficient?"(Abdel Haleem,2004:425). }\end{array}$ \\
\hline Translit. & " Wawajadaka AAạilan faaghna \\
\hline
\end{tabular}

According to Omar, et al.(2008), 'faa $w \underline{a}$ ' means sheltering and caring for

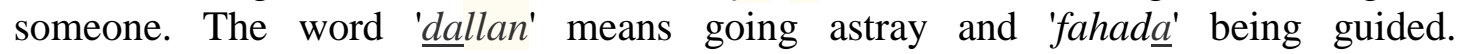
Furthermore, the words 'AAailan' and 'faaghna' mean to be poor and to be enriched.

Allah reminds the prophet Muhammed in these verses that in the past he was an orphan but He sheltered him by having his grandfather Abdelmuttalib and his uncle Abu Talib embrace him after his parents' death. Also, Allah found him bewildered in a pagan society and an environment where people adopted a deviant thought and $\mathrm{He}$ showed him the right way. In addition, Allah enriched him after he suffered from poverty. The prophet was reminded of this part of his past in order not to be upset due to disbelievers' claim that Allah abandoned him because of the stoppage of the revelation for a certain period of time(Al-Razī,1981;Qutb,1992). Based on Searle (1969), as a form, these verses occur as rhetorical questions which are considered representative speech acts. But they are indirect speech acts of commissive of promising pragmatic function in which Allah promises the prophet to care for him and never leave him alone in carrying the burdens of the message. Moreover, the pragmatic function that lies in the verses above is that it is incredibly and beautifully motivating to indirectly tell a person who feels bad that very soon everything will be fine and things will be going very well. Then, Allah has given the prophet many more reasons to convince him that Allah's promises will verily come true. First, Allah found him an orphan and looked after him. Second, Allah found him perplexed and $\mathrm{He}$ guided him. Third, Allah found him poor and he has given him wealth. Then, the best way to comfort a depressed person is to remind him of the past blessings that can be gifted again and again. 
(36) (30)

اذار - هارس 2019

مجلة الفنون والندبوعلور الإنسانيات واللاجتهاع

Table (1): Frequency of Occurrence of Direct and Indirect Speech Acts and Their Pragmatic Functions in Surah Ad- dhuha (Morning Light)

\begin{tabular}{|c|c|c|c|c|}
\hline SA & \multicolumn{2}{|c|}{ Directives } & \multicolumn{2}{|c|}{ Commissives } \\
\hline & Direct & Indirect & Direct & Indirect \\
\hline $\mathbf{P F}$ & Ordering & Ordering & Promising & Promising \\
\hline $\mathbf{F r}$. & 3 & I & / & 8 \\
\hline Pc. & $27 \%$ & I & I & $72 \%$ \\
\hline
\end{tabular}

\subsubsection{Analysis of Surah Ash-sharh (The Relief)}

It is a very short surah which consists of eight verses. All the verses fall into two kinds of illocutionary speech acts which are directives and commissives. Only two pragmatic functions such as ordering and promising occur in this surah. As for the context of situation of this surah, it was revealed to the prophet Muhammed in the initial stage of his prophethood to give him hope and encouragement when he faced many difficulties in his task of converting people to Islam ( Ali, 1998).

\section{Direct and Indirect Speech Acts of Directive:}

In the surah under analysis, there is no any reference to indirect speech acts of directive. Only two instances of direct speech acts of directive of ordering pragmatic function occur forming $25 \%$ out of the total (8). Consider the following example:

\begin{tabular}{|c|c|}
\hline ST & 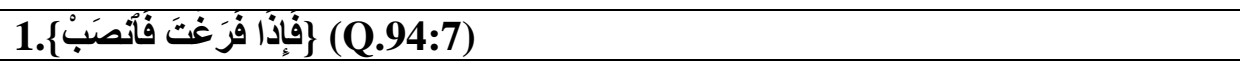 \\
\hline Trans. & $\begin{array}{l}\text { " The moment you are freed [of one task] work on"(Abdel Haleem, } \\
\text { 2004:426). }\end{array}$ \\
\hline Translit. & "Faitha faraghta fainsab" \\
\hline
\end{tabular}

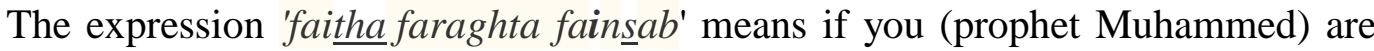
free from your duties, exert yourself in invocation or supererogatory prayers(Ibn Manzur,1997). In this verse, Allah orders the prophet Muhammed to exert in supplication to Him after performing prayers as a gratitude to Him for His bounties like soothing his heart, facilitating the burden of the message...etc.(Al-Razī,1981; Qutb,1992). Based on Searle(1969), there is no contrast between the structure and the function of the utterance above, so, it is an instance of direct speech act of directive of ordering pragmatic function. 


\section{Direct and Indirect Speech Acts of Commissive:}

This type of speech acts in the surah under study is extensively performed. All the examples of this type are indirect speech acts of promising pragmatic function which occur six times making up $75 \%$ out of the total(8). See the following examples:

\begin{tabular}{|c|c|}
\hline ST & 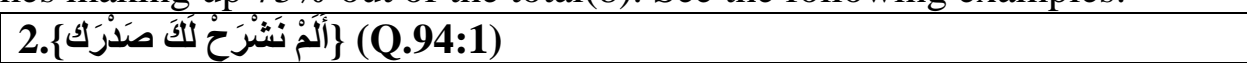 \\
\hline Trans. & $\begin{array}{l}\text { "Did We not relieve your heart for you [Prophet]"(Abdel Haleem, } \\
\text { 2004:426). }\end{array}$ \\
\hline Translit. & "Alam nashrah laka sadraka" \\
\hline
\end{tabular}

According to IbnManzur (1997), the expression 'sharaha Allahu sadraho' (God has widened one's heart) indicates that Allah has provided the prophet Muhammed with the readiness to accept what is good and right.

In the verse above, Allah asks a rhetorical question in which He asserts that $\mathrm{He}$ soothed the prophet's heart by means of prophethood, knowledge and obedience. So, He did so to make the prophet be able to do all the tasks entrusted to him without anxiety, boredom or change (Al-Razī1981;Qutb,1992). Based on Searle (1969), although this verse occurs in the form of a rhetorical question which is considered a speech act of representative of asserting pragmatic function, it asserts the pragmatic meaning of an indirect speech act of commissive of promising. Accordingly, it seems that the intended pragmatic function (in verse1) is indirectly stressing the fact that Allah has provided and will provide the prophet with the required potentials to deliver the message of Islam to all mankind, starting with softening his chest to grasp what is good.

\begin{tabular}{|c|c|}
\hline ST & 3. 3. \\
\hline Trans. & "and remove the burden"(Abdel Haleem, 2004:426) \\
\hline Translit. & "WawadaAAna AAanka wizraka" \\
\hline
\end{tabular}

\begin{tabular}{|c|c|}
\hline ST & 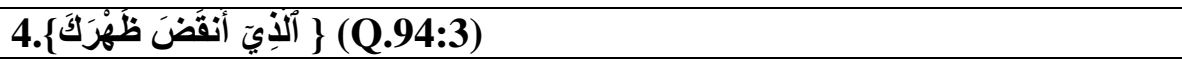 \\
\hline Trans. & "that weighed so heavily on your back"(Abdel Haleem,2004:426). \\
\hline Translit. & "Allathee anqada thahraka" \\
\hline
\end{tabular}

IbnManzur (1997) states that the words ' wawadaAAna AAanka wizraka 'means removing your heavy burden. The expression 'Allathee anqada thahraka ' means the hidden sound that your back makes when it is weighed down by a heavy burden.

Allah in the two aforementioned verses affirms that He relieved the prophet Muhammed's burden which is the message he was entrusted with to convey to people by providing and facilitating the ways for that (Al-Razī1981;Qutb,1992). The two verses mentioned above involve two figurative meanings which are 'wizr' (the burden) referring to the message and 'ainqad athhr (weighing down the back) standing for the worries of conveying the message to people. They include the same meaning embedded in the first verse that Allah promises to guide the prophet as to how to carry the message and remove the worries caused by the conspiracies of disbelievers against it. By this way, his burden will be lifted. In the light of Searle's(1969) model, the speech acts of these verses are not examples of representatives of asserting pragmatic function, rather, they are indirect speech acts of commissive of promising pragmatic function. 
(36) العدב

اذار - عارس 2019

مجلة الفنون والندب علوم الإنساتيات والاجتهاع

Table (2): Frequency of Occurrence of Direct and Indirect Speech Acts and Their Pragmatic Functions in Surah Ash-sharh (The Soothing)

\begin{tabular}{|c|c|c|c|c|}
\hline SA & \multicolumn{2}{|c|}{ Directives } & \multicolumn{2}{c|}{ Commissives } \\
\hline & Direct & Indirect & Direct & Indirect \\
\hline FF & Ordering & Ordering & Promising & Promising \\
\hline Fr. & 2 & $/$ & $/$ & 6 \\
\hline Pc. & $25 \%$ & $/$ & $/$ & $75 \%$ \\
\hline
\end{tabular}

The occurrence of direct and indirect speech acts in surah Ad-dhuha and surah Ash-sharh might be determined by some reasons. The following table below shows that their frequency of occurrence is varied:

Table (3): Frequency of Occurrence of Direct and Indirect Speech Acts in Surah Ad-dhuha and Surah Ash-sharh

\begin{tabular}{|l|c|c|c|c|c|c|c|c|}
\hline \multirow{2}{*}{} & \multicolumn{3}{c|}{ Surah Ad-dhuha } & \multicolumn{4}{c|}{ Surah Ash-sharh } \\
\cline { 2 - 10 } & Directives & \multicolumn{2}{c|}{ Commissives } & \multicolumn{2}{c|}{ Directives } & \multicolumn{2}{c|}{ Commissives } \\
\cline { 2 - 10 } $\begin{array}{l}\text { Direct } \\
\text { Speech } \\
\text { Acts }\end{array}$ & No. & P.c. & No. & P.c. & No. & P.c. & No. & P.c. \\
\hline
\end{tabular}

Taking the table above into account, it has been shown that commissives occur more frequently than directives in surah Ad-dhuha and surah Ash-sharh. All the direct speech acts in the aforementioned surahs are directives of ordering pragmatic function and they have frequencies of occurrence which are (27\% and $25 \%)$ put orderly. In addition, all the indirect speech acts in the previously mentioned surahs are 
commissives of promising pragmatic function and their frequencies of occurrence are (72\% and $75 \%$ ) respectively. Such occurrence might be ascribable to the circumstances in which the these short surahs were revealed like the stoppage of the revelation in a while and the gloomy life the prophet Muhammed lived and burdens he shouldered to convey the message of Islam to people. The verses occurring as commissives of promising pragmatic function like the verses occurring in the form of rhetorical questions or as statements in which Allah reminded his prophet of his past life which was full of bounties in these two surahs are performed as indirect speech acts to strongly affect him and get him out of the gloomy mood he was in. Moreover, directives in both surahs which involve orders stressing the importance of performing the religious duties towards Allah, safeguarding the rights of the oppressed in an environment where the powerless like orphans were oppressed and could not get their rights and not driving away the beggars are intended to motivate the recipients ( the prophet and the believers) to strictly follow them. That's why, they are performed as direct speech acts (see Qutb,1992).

\subsection{Conclusions}

In the light of the previous analysis of the two short surahs, the following findings have been arrived at:

1- In surah Ad-dhuha, two types of illocutionary speech acts which are directives and commissives occur. Only two different pragmatic functions (ordering and promising) occur within these types of speech acts. Concerning directives, all the examples occurred are of direct speech acts of ordering pragmatic function and their frequency of occurrence is $(27 \%)$. As for commissives, only indirect speech acts occur. All the examples are of promising pragmatic function which has $(72 \%)$ frequency of occurrence. After the discontinuation of the revelation, this surah was revealed as a consolation to the prophet Muhammed. Furthermore, Allah promises to reward and give him many bounties in his later life, that's why, the commissives occur more frequently than directives.

2- Regarding surah As-sharah, directives and commissives are the only types of speech acts occur. All the examples of directives are direct speech acts of ordering pragmatic function with $(25 \%)$ frequency of occurrence. Commissives involve only indirect examples of promising pragmatic function with $(75 \%)$ frequency of occurrence. The frequency of occurrence of commissives which is higher than that of directives might be attributable to the situation in which this surah was revealed. The prophet Muhammed faced many difficulties in conveying the message of Islam to others, so, Allah promised to please and be with him at all times.

3- The occurrence of the speech acts as direct or indirect in the two short surahs might be determined by the circumstances in which they were revealed in addition to the effect intended to achieve on the recipients. 


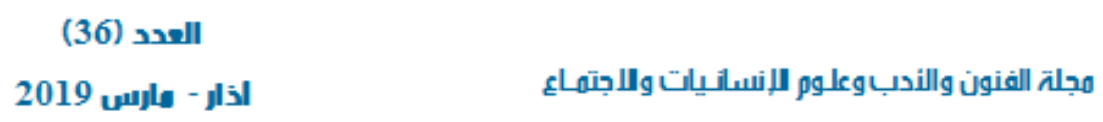

References

1. Abdel Haleem, M.A.S.(2004).The Qur'an. Oxford: Oxford University Press.

2. Ali, A. Y. (1998). The Holy Qur'an: Original Arabic Text with English Translation and Selected Commentaries. Kuala Lumpur: Saba Islamic Media.

3. Allan, K. (1986).Linguistic Meaning. Vol. 2. London: Routledge.

4. Al-Razī, M. F. (1981).Al-Tafsir Al-kabir. Beirut: Dar al-Fikr.

5. Al-Saaidi, S.K., Al-Shaibani, G.K. and Al-Husseini, H.A.M.(2013).

6. Speech Acts of Prohibition in English and Arabic: A Contrastive Study on

7. Selected Biblical and Quranic Verses. AWEJ, 4 (4), pp.95-111.

8. Al-Saidi, Ali.H.(2016). Socio-pragamtic Failure in the English Translations of the Euphemstic Culture-bound Expressions in the Qur'an by Non-Nuslim Translators. (Ph.D. Thesis), KL.UPM Press.

9. Amin, N. and Safa H.H. (2016).Analysis Speech Act Imperative In Alquran. ADVANCES in NATURAL and APPLIED SCIENCES. Pp.1-9.

10. Austin, J.(1962).How to Do Things with Words. Oxford :Oxford: Oxford

11. University Press.

12. Bach, K. and Harnish, R. M. (1979).Linguistic Communication and

13. Speech Acts .Cambridge: The MIT Press.

14. Baker, M. (1992). In Other Words. London: Routledge

15. Caulthard, M. (1985).An Introduction to Discourse Analysis. London: Longman

16. Group Ltd.

17. Cruse, A.(2006). A Glossary of Semantics and Pragmatics. Edinburgh: Edinburgh

18. University Press.

19. Crystal, D. (2003). A Dictionary of Linguistics and Phonetics. London: Blackwell.

20. Fromkin, V., Rodman, R. and Hyams, N.( 2007). An Introduction to

a. Language. ( $8^{\text {th }}$ ed.). Thomason: Wadsworth.

b. Huang, Y. (2012). The Oxford Dictionary of Pragmatics. Oxford: Oxford University Press.

21.

Language and

(2006). Speech Acts. In Brown, k.(ed.), Encyclopedia of

a. linguistics (Vol.1)( $2^{\text {nd }}$ ed. ). (Pp.656-665).Oxford: Elservier Science.

22. Ibn Manzŭr, A. G. (1997). Lisan Al- Arab. Beirut: Dar Sader Publishers.

23. Issa, M. M (2015). The Translation of Requests in the Holy Quran: A Contrastive Study between Arabic and English.(Unpublished MA Thesis). Retrieved from https://scholar.najah.edu/sites/default/files) /

24. Jauharin, K.(2014). Directives in the Translaton of the Quran Surah

25. alBaqarah. (MA Thesis). Retrieved from www.eprints.umk.ac.id/2945/1/HALAMAN_JUDUL.pdf

26. Leech, G. ( 1983 ).Principles of Pragmatics .London : Longman.

27. Levinson, S.(1983). Pragmatics. Cambridge: Cambridge University Press.

28. Mawadda, Z. U.(2016). Commissive Utterances in the Translation of the Holy Quran Chapter Joseph : A pragmatic Perspective. Retrieved from www.eprints.ums.ac.id/48148/11/publication\%20article.pdf 


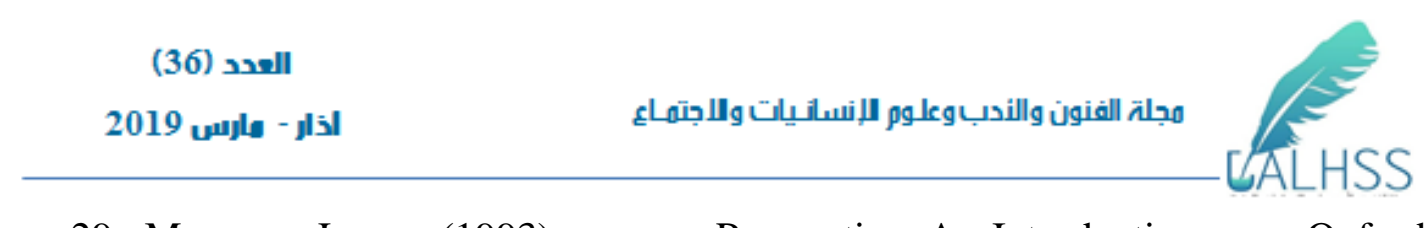

29. Mey, J. (1993). Pragmatics: An Introduction. Oxford:

Basil Blackwell.

30. Omar, A. M. and et al .( 2008). Mu'jam Allugha Alarabiyia Almu'asira.(Vol. 1) (1 ${ }^{\text {st }}$ ed.).Cairo: Aalam Alkutub.

31. Qutb, S. (1992). Fee Dhilal AI-Qur 'an. Beirut: Dar AI-Shorooq.

32. Santosa, R. B., Nurkamto, J., Baidan,N. and Sumarlam (2016). Pragmatic Study of Directive Speech Acts in Stories in Alquran. Advances in Language and Literary Studies, 7 (5), pp. 78-84.

33. Searle, J. (1979). Expression and Meaning. Cambridge: Cambridge University Press.

34. Verschueren, J. (1999). Understanding Pragmatics . London: Arnold.

35. Yule, G. (1996). Pragmatics.Oxford : Oxford University Press.

36. https://www.islamicfinder.org/quran/surah-addhuhaa/11/?translation=english-abdul-majid-daryabadi

37. https://www.islamicfinder.org/quran/surah-ash-sharh/1/?translation=englishabdul-majid-daryabadi 


\section{Appendix A}

\section{Surah Ad-dhuha( The Morning Brightness)}

\begin{tabular}{|c|c|c|c|}
\hline No & +2 & S.P. & P.F. \\
\hline 1- & 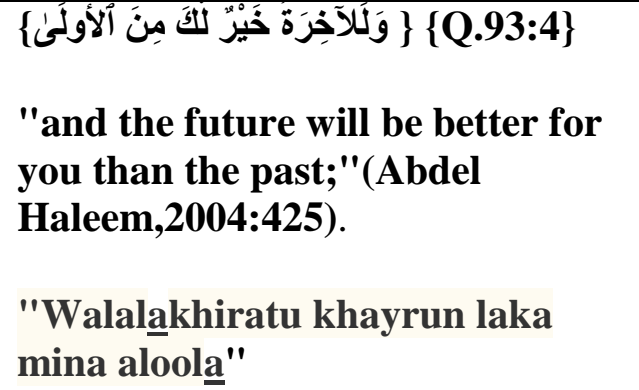 & Commissive (indirect) & Promising \\
\hline $2-$ & 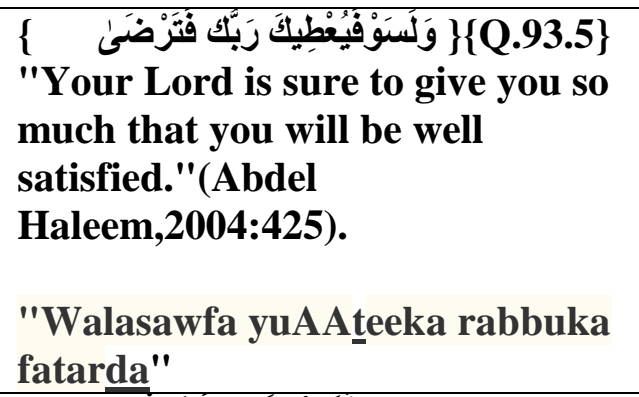 & Commissive (indirect) & Promising \\
\hline 3- & 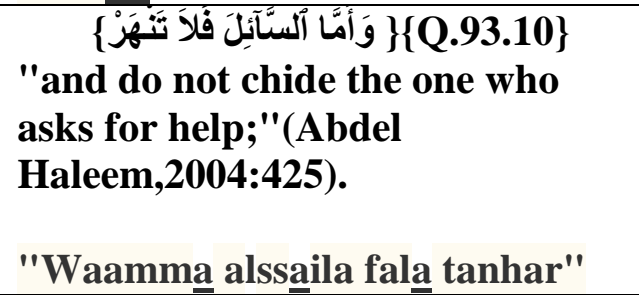 & Directive( direct) & Ordering \\
\hline 4- & 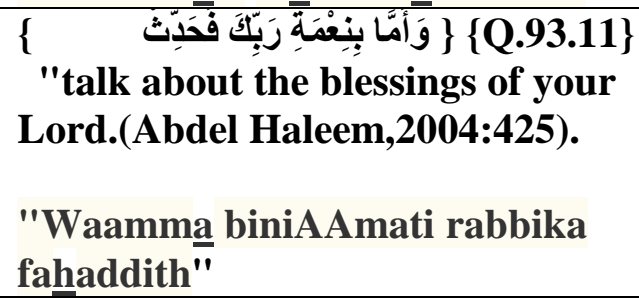 & Directive( direct) & Ordering \\
\hline
\end{tabular}




\section{Appendix B}

Surah Ash-sharh( The Relief)

\begin{tabular}{|c|c|c|c|}
\hline No. & V. & S.P. & P.F. \\
\hline 1- & 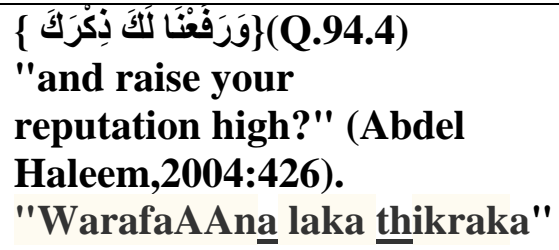 & Commissive ( indirect) & Promising \\
\hline $2-$ & 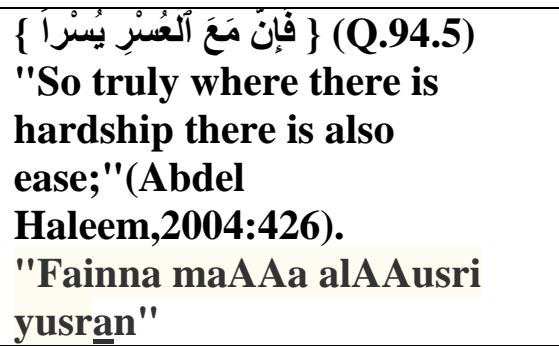 & Commissive ( indirect) & Promising \\
\hline 3- & 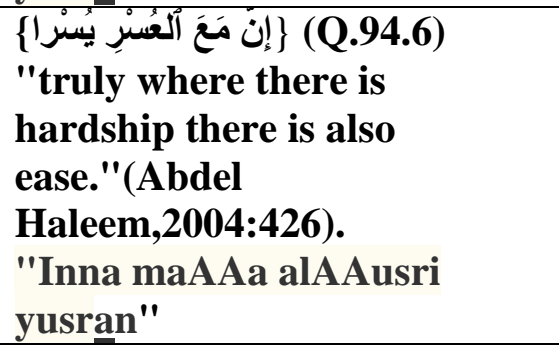 & Commissive ( indirect) & Promising \\
\hline 4- & 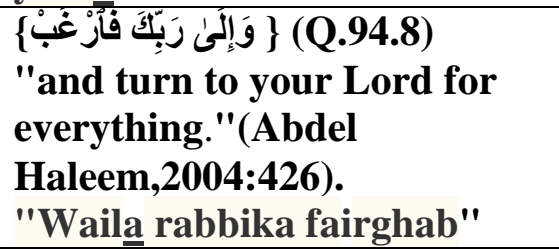 & Directive (direct) & Ordering \\
\hline
\end{tabular}

